\title{
Formation, properties and reactivity of coprecipitates and organomineral complexes in soil environments
}

\author{
Antonio Violante ${ }^{1}$, Maria de La Luz Mora ${ }^{2}$ and Antonio G. Caporale ${ }^{1^{*}}$ \\ ${ }^{1}$ Dipartimento di Agraria, Università di Napoli Federico II, Portici (Napoli) Italy. ${ }^{2}$ Departamento de Cien- \\ cias Quimicas y Resurses Naturales, Universidad de La Frontera, Temuco, Chile. *Corresponding author: \\ ag.caporale@unina.it
}

\begin{abstract}
In soil environments the formation of simple coprecipitates formed by the interaction of two or more cations and/or anions are the rule and not the exception. In this review we describe the formation, the nature and the reactivity of coprecipitates formed by the interaction between cations ( $\mathrm{Fe}, \mathrm{Al}, \mathrm{Mg}, \mathrm{Mn}, \mathrm{Zn}$ ) with the formation of mixed oxides or layered double hydroxides (LDHs) and of coprecipitates formed by the interactions of inorganic and low molecular mass organic (LMMOLs) ligands with $\mathrm{OH}-\mathrm{Al}$ and/or $\mathrm{OH}-\mathrm{Fe}$ species both in the absence or presence of phyllosilicates. The presence of anions within these samples strongly affect the sorption of other ligands on the surfaces of the coprecipitates. Furthermore, the anions coprecipitated with $\mathrm{Al}$ and/or Fe hydrolytic products are only partially replaced even by ligands with strong affinity for the surfaces of the final samples, clearly because they are also incorporated into the network of the precipitates. We also describe the formation, surface properties and reactivity of binary complexes obtained by the interaction of hydrolytic products of $\mathrm{Al}$ and $\mathrm{Fe}$ with clay minerals and of ternary $\mathrm{OH}-\mathrm{Al}(-\mathrm{Fe})$-organics-phyllosilicates (organics included also large anions as tannate or proteins). The effect of the sequence of addition of the components of the final organomineral complexes influenced the physicochemical and mineralogical properties of the samples. Attention was also devoted to the stabilization of organic substances in organo-mineral coprecipitates and soils.
\end{abstract}

Keywords: Soil, coprecipitates, clay minerals, organic biomolecules, organomineral complexes, chemical properties 


\section{Introduction}

Phyllosilicates, organic substances, microorganisms, carbonates, and variable charge minerals, whose charge varies with $\mathrm{pH}$ (including crystalline and noncrystalline $\mathrm{Al}, \mathrm{Fe}, \mathrm{Mn}$ and Ti oxides and short-range ordered aluminosilicates) as well as clay minerals coated by $\mathrm{OH}-\mathrm{Al}(-\mathrm{Fe})$ species, are the major solid components of the soils (Sparks, 2003; Violante et al., 2008). These components are constantly in close association with each other, forming organomineral complexes with peculiar chemical and physicochemical properties (shape, size, charge) and reactivity towards nutrients and pollutants (Violante, 2013). To date scientific accomplishments in individual disciplines of the physics, chemistry and biology of soils are impressive, but studies on the interactions of soil minerals with organic substances and microorganisms were fragmentary and scattered in the literature of soil and environmental sciences. Only in the last decades the formation, physicochemical properties and reactivity of synthetic and natural simple coprecipitates or organomineral complexes received attention. According to Yuan and Theng (2013) "soil may be regarded as a complex bioorganomineral system where organic matter (humus), minerals, water, air, and microorganisms interact at scales ranging from nanometers to kilometers. The interaction between clay minerals and organic matter is of fundamental importance in stabilizing organic matter against decomposition by microorganisms (Calabi-Floody et al., 2011; CalabiFloody et al., 2015; Kögel-Knabner and Amelung, 2014; Matus et al., 2014).

The formation of relatively simple coprecipitates obtained by the interactions among cations and/or anions is of paramount importance in soils and related environments. For example, nanocoprecipitates may easily form by the interaction between cations (e.g. Fe, Al, $\mathrm{Mn}$ ) forming mixed oxides or by coprecipitation of nutrients or pollutants, both in cationic and anionic forms, with $\mathrm{OH}-\mathrm{Al}$ and/or $\mathrm{OH}-\mathrm{Fe}$ species forming binary and ternary or more complex systems. In few words, some cations and anions may interact each other forming at certain $\mathrm{pHs}$ nanocoprecipitates of different mineralogy, surface properties and reactivity. These materials may exist as separate entities, but usually they are strongly associated to minerals, organic matter and organomineral complexes (Huang and Germida, 2002; Violante et al., 2008).

Some coprecipitates may form on the surfaces of clay minerals, because for trace elements direct precipitation or coprecipitation from solution is unlikely for their low concentration in soil solution. Many studies have been carried out on the heterogeneous coprecipitation of trace elements on the external surfaces of minerals using modern spectroscopy techniques such as synchrotron-based x-ray absorption spectroscopy (Sparks, 2003; Borda and Sparks, 2008). Reported observations include zinc precipitates on calcite, cobalt precipitates on $\mathrm{Al}_{2} \mathrm{O}_{3}$, polynuclear chromium (III) hydroxide structures on silica and goethite, and the formation of mixed nickel-aluminum hydroxides on pyrophyllite. More information on these studies were reported by Borda and Sparks (2008).

In our laboratory researches have been carried out on the formation and nature of synthetic coprecipitates which may form in natural environments. In this review we summarize most of the findings of our studies on the formation, nature and reactivity of some important and relatively simple coprecipitates formed by (i) the interaction between cations $\mathrm{Fe}, \mathrm{Al}, \mathrm{Mg}, \mathrm{Mn}$, $\mathrm{Zn}$ [with the formation of e.g. mixed Fe-Al copolymers or oxides and layered double hydroxides (LDHs)], and (ii) by the coprecipitation of anions [(e.g. organic ligands, phosphate $(\mathrm{P})$, sulfate $(\mathrm{S})$, arsenate $\mathrm{As}(\mathrm{V})$, arsenite $\mathrm{As}(\mathrm{III})]$ with hydrolytic products of $\mathrm{Al}$ or $\mathrm{Fe}$ 
ions both in the absence (binary systems) or presence (ternary systems) of clay minerals. Special attention is given to the interaction between inorganic and organic soil components with the formation of more complex coprecipitates and on their chemical, physicochemical, mineralogical properties and reactivity. This review also aims to provide information on the current state of knowledge reported in the literature on these important topics.

\section{Formation, nature and reactivity of simple copre- cipitates (binary systems)}

Coprecipitation of cations and anions occurs easily in natural systems. Iron or Al may precipitate alone forming many $\mathrm{Fe}$ - or Al-oxides of different crystallinity, mineralogy, surface properties and reactivity (Cornell and Schwertmann, 1996), but they may also coprecipitate each other, in the absence or presence of organic ligands, forming mixed $\mathrm{Fe}-\mathrm{Al}$ oxides. Iron(III) and $\mathrm{Al}$ may also coprecipitate with other bivalent cations such as $\mathrm{Mg}, \mathrm{Fe}(\mathrm{II}), \mathrm{Zn}, \mathrm{Cu}$ forming mixed oxides, such as layered double oxides (LDHs) (Caporale et al., 2011; Caporale and Violante, 2016; Pigna et al., 2016).

In soils, the coprecipitates obtained by the interaction between inorganic (nutrients and pollutants) and organic ligands with $\mathrm{Al}$ and/or $\mathrm{Fe}$ are of paramount importance. The anions, are not only held on the external surfaces of the final precipitates, but may be present into the network of the coprecipitates, showing different mobility if compared with the same ligands sorbed onto the external surfaces of $\mathrm{Al}$ and $\mathrm{Fe}$ oxides (as discussed below).

\section{Mixed Fe-Al coprecipitates}

The interaction between $\mathrm{Fe}$ and $\mathrm{Al}$ in the crystallization process of Fe-oxides has been reported in detail (Cornell and Schwertmann, 1996). Many studies have demonstrated that in soil environments $\mathrm{Fe}$ and $\mathrm{Al}$ ions may interact each other forming mixed oxides of different chemical composition, size, nature and reactivity. For instance, after prolonged aging of mixed Al-Fe systems, crystallization of $\mathrm{Al}(\mathrm{OH})_{3}$ and mixed noncrystalline $\mathrm{Fe}-\mathrm{Al}$ oxide or highly Al-substituted noncrystalline Fe-oxides formed at pH 6-7. Later, Colombo and Violante (1996) demonstrated that the initially formed mixed products are metastable and slowly convert, depending on the initial $\mathrm{Fe} / \mathrm{Al}$ molar ratio (R), through different soluble and short-range ordered species into more stable $\mathrm{Al}$ and Fe oxides, mainly gibbsite and hematite (Figures 1 and 2). The distribution of $\mathrm{Fe}$ and $\mathrm{Al}$ in soluble or solid phases of different sizes depends on $\mathrm{R}, \mathrm{pH}$ and aging period (Figure 2). Usually, the higher $R$, the higher the amounts of $\mathrm{Fe}+\mathrm{Al}$ present in soluble or colloidal particles. These authors determined the chemical composition of the fractions $>0.2,0.02-0.01$ and $<0.01 \mu \mathrm{m}$. The percentages of $\mathrm{Fe}+\mathrm{Al}$ present in the $<0.01 \mu \mathrm{m}$ fractions of the samples R0-R1 ranged from $18 \%$ (R0) to $46 \%$ R0.5 after $7 \mathrm{~d}$, but from $15 \%$ (R0) to $<5 \%$ (R0.5 and R1) after $120 \mathrm{~d}$. The high stability of mixed Fe-Al species has been demonstrated. In unmixed $\mathrm{Al}$ or Fe solutions gibbsite or hematite and/or goethite crystallized in a few days or weeks at $\mathrm{pH} 5.0$ and $50{ }^{\circ} \mathrm{C}$, whereas in the Fe-Al samples, the formation of well crystallized Fe oxides was not evident at $\mathrm{R} \geq 1$ even after 32-120 days at $50^{\circ} \mathrm{C}$ (Colombo and Violante, 1996).

Violante et al. (1998) found that samples formed at $\mathrm{pH}$ values ranging from 4.0 to 10.0 and $\mathrm{R}$ of 1 or 2.5 showed considerable differences in the mineralogy of the precipitates after 60 days at $50{ }^{\circ} \mathrm{C}$. The samples formed at $\mathrm{R}=1$ contained ferrihydrite at $\mathrm{pH} 4.0$, ferrihydrite+gibbsite at $\mathrm{pH}$ 5.0-7.0, and hematite $+\mathrm{Al}(\mathrm{OH})_{3}$ polymorphs + ferrihydrite at $\mathrm{pH}$ 9.0-10.0. The coprecipitates formed at $\mathrm{R}=2.5$ had greater quantities of ferrihydrite. In fact, large amounts of $\mathrm{Al}+\mathrm{Fe}(25-85 \%)$ were solubilized from these samples by ammonium oxalate. 
Citrate added initially to Fe-Al solutions (citrate/ $\mathrm{Fe}+\mathrm{Al}=0.1$ and $\mathrm{Fe} / \mathrm{Al}=1$; ternary complexes) completely inhibited the formation of crystals at $\mathrm{pH} 5$ or 8.5 even after 135 days at $50^{\circ} \mathrm{C}$ (Violante et al., 1998).
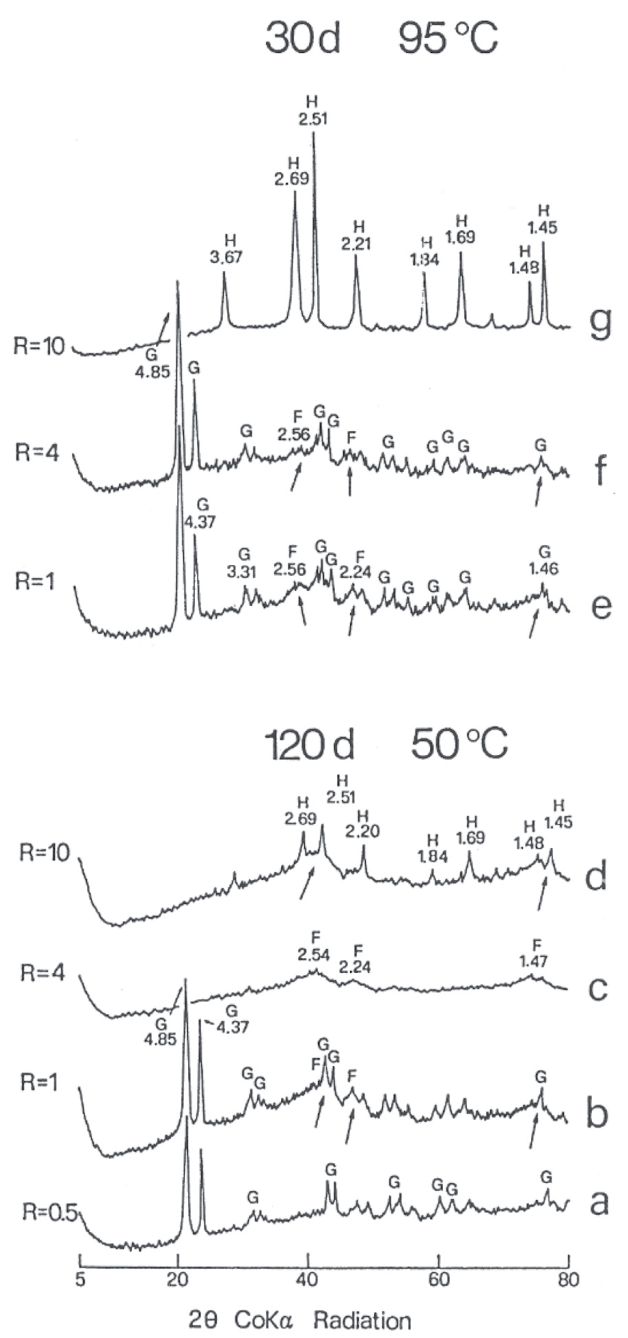

Figure 1. X-ray powder diffractograms of the $\mathrm{Fe}-\mathrm{Al}$ coprecipitates aged $120 \mathrm{~d}$ at $50{ }^{\circ} \mathrm{C}$ and $32 \mathrm{~d}$ at $50{ }^{\circ} \mathrm{C}$ plus $30 \mathrm{~d}$ at $95^{\circ} \mathrm{C}$. R indicates the initial $\mathrm{Fe} / \mathrm{Al}$ molar ratio. $\mathrm{H}$ stands for Hematites, $\mathrm{F}$ for Ferrihydrite and $\mathrm{G}$ for Gibbsite. The arrows indicate a possible presence of Ferrihydrite.
Fe-Al coprecipitates showed different reactivity towards anions and cations if compared to $\mathrm{Al}$ or $\mathrm{Fe}$ oxides. Violante et al. (2003) carried out a study on the sorption of $\mathrm{Co}^{2+}, \mathrm{Cu}^{2+}, \mathrm{Pb}^{2+}$, and $\mathrm{Zn}^{2+}$ ions on mixed $\mathrm{Fe}-\mathrm{Al}$ oxides. Mixed $\mathrm{Fe}-\mathrm{Al}$ oxides were prepared by precipitating at $\mathrm{pH} 5.5$ mixtures of $\mathrm{Fe}$ and $\mathrm{Al}$ ions at $\mathrm{R}$ of $0,1,2,4,10$ and $\infty$ (R0, R1, $\mathrm{R} 2, \mathrm{R} 4, \mathrm{R} 10$ and $\mathrm{R} \infty$ ). The oxides aged 7 days at 20 ${ }^{\circ} \mathrm{C}$ showed presence of short range ordered materials (aluminous ferrihydrite for R1-R $\infty$ or noncrystalline Al-oxide for R0) and similar surface area (200-285 $\mathrm{m}^{2} / \mathrm{g}$ ). The heavy metals were selectively sorbed on the oxides. A measure of the relative affinity of the heavy elements for an oxide is given by the $\mathrm{pH}$ at which $50 \%$ of the original cation is sorbed, termed pH50 (Violante et al., 2003; 2005). The pH50 values of $\mathrm{Pb}, \mathrm{Cu}, \mathrm{Zn}$ and $\mathrm{Co}$ sorbed on the noncrystalline Al-oxide, ferrihydrite and mixed Fe-Al oxides (R1R10) were different from sample to sample (Table 1 ; Figure 3). It can be seen from the data reported in Table 1 that the pH50 value of the samples R0 to R4 decreased with increase in $\mathrm{Fe}$ content of the $\mathrm{Fe}-\mathrm{Al}$ oxides. For example, the $\mathrm{pH} 50$ value of $\mathrm{Pb}$ decreased from 5.01 for R0 to 4.35 for $\mathrm{R} \infty$. In other words, the $\Delta \mathrm{pH} 50$ ( $\mathrm{R} 0$ to $\mathrm{R} \infty$ ) for $\mathrm{Pb}, \mathrm{Cu}, \mathrm{Zn}$ and $\mathrm{Co}$ was $0.66,0.76,0.34$ and 0.30 , respectively. The mixed Fe-Al oxides clearly showed different sorption affinity, particularly for metals (e.g., $\mathrm{Pb}$ and $\mathrm{Cu}$ ), which are more selectively sorbed. It appears evident that the greater the selectivity of a heavy metal for the gels, the greater the $\mathrm{pH} 50$ from the noncrystalline Al-hydroxide (R0) to ferrihydrite (Rœ).

These results indicate that the mixed $\mathrm{Fe}-\mathrm{Al}$ oxides were not simple mixtures of different amounts of Feand Al-oxides, but oxides with different mineralogy, chemical composition, surface properties (Colombo and Violante, 1996; Violante et al., 2003) and therefore reactivity toward cations and anions. 

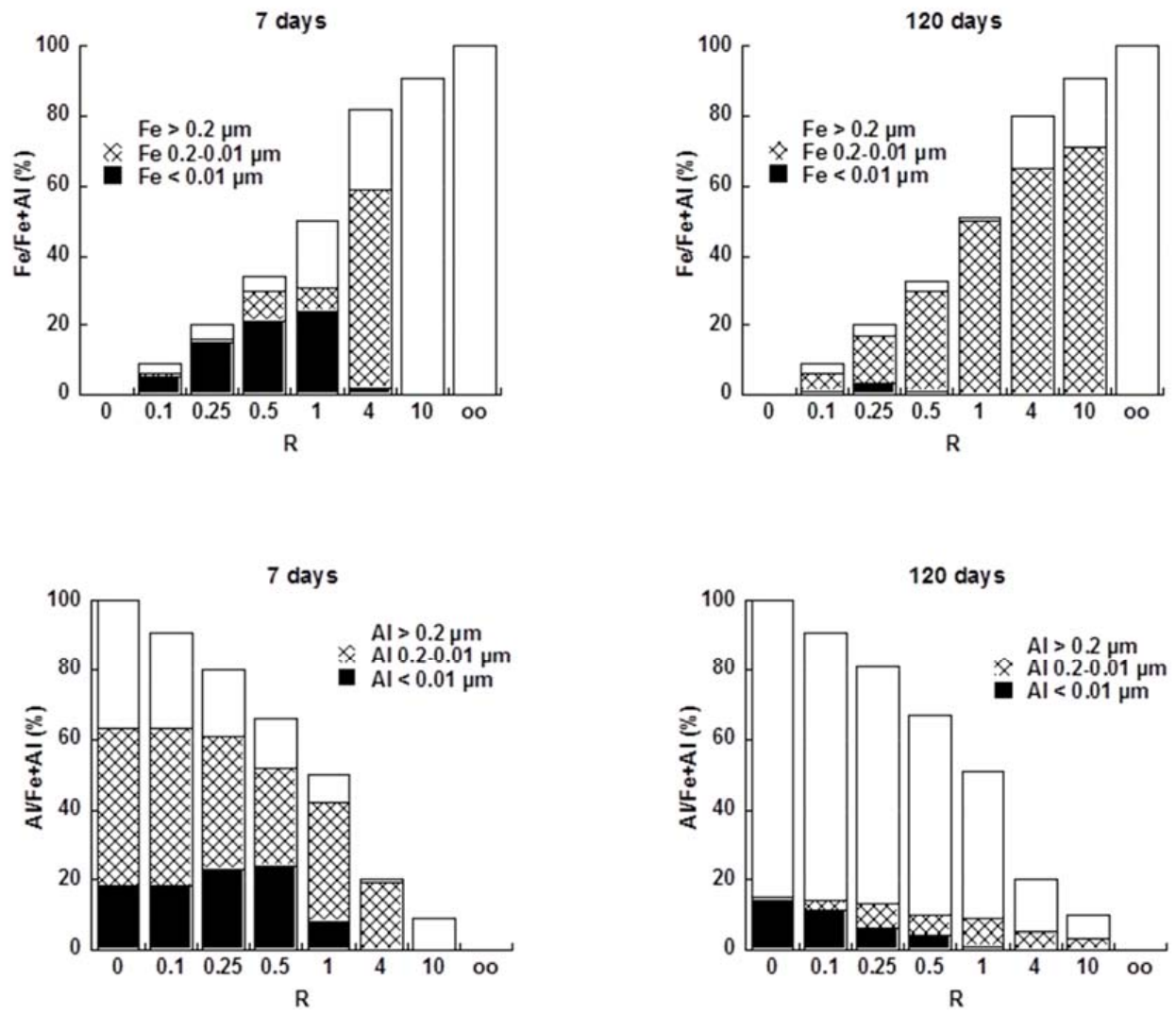

Figure 2. Percentages of $\mathrm{Fe}$ and $\mathrm{Al}$ in the fractions $>0.2 \mu \mathrm{m}$, between $0.2-0.01 \mu \mathrm{m}$ and $<0.01 \mu \mathrm{m}$ of the $\mathrm{Fe}-\mathrm{Al}$ coprecipitates aged at 7 and $120 \mathrm{~d}$ at $50{ }^{\circ} \mathrm{C}$. $\mathrm{R}$ indicates the initial $\mathrm{Fe} / \mathrm{Al}$ molar ratio.

Table 1. Value of $\mathrm{pH} 50^{\mathrm{a}}$ for $\mathrm{Pb}, \mathrm{Cu}, \mathrm{Zn}$ and $\mathrm{Co}$ sorbed onto selected crystalline and short-range-ordered metal oxides.

\begin{tabular}{ccccc}
\hline Samples & $\mathrm{Pb}$ & $\mathrm{Cu}$ & $\mathrm{Zn}$ & $\mathrm{Co}$ \\
\hline Noncrystalline & --- & --- & --- & --- \\
Al-hydroxide $(\mathrm{R} 0)^{\mathrm{b}}$ & 5.01 & 6.24 & 6.73 & 7.77 \\
Fe-Al-oxide $(\mathrm{R} 1)^{\mathrm{b}}$ & 4.91 & 5.59 & 6.46 & 7.73 \\
$\mathrm{Fe}-\mathrm{Al}$-oxide $(\mathrm{R} 2)^{\mathrm{b}}$ & 4.79 & 5.56 & 6.42 & 7.59 \\
Fe-Al-oxide $(\mathrm{R} 4)^{\mathrm{b}}$ & 4.49 & 5.47 & 6.41 & 7.47 \\
Fe-Al-oxide $(\mathrm{R} 10)^{\mathrm{b}}$ & 4.35 & 5.35 & 6.38 & 7.47 \\
Ferrihydrite $(\mathrm{R}=\infty)^{\mathrm{b}}$ & 4.35 & 5.29 & 6.39 & 7.47 \\
\hline
\end{tabular}

${ }^{a} \mathrm{pH} 50$ indicates the $\mathrm{pH}$ at which $50 \%$ of the original cation was sorbed. ${ }^{\circ} \mathrm{R} 0, \mathrm{R} 1, \mathrm{R} 2, \mathrm{R} 4, \mathrm{R} 10$, and Ro indicate the initial Fe/ Al molar ratio.The sample R0 showed the presence of poorly crystalline gibbsite; the R1-R10 samples showed the presence of (aluminous) ferrihydrite. 

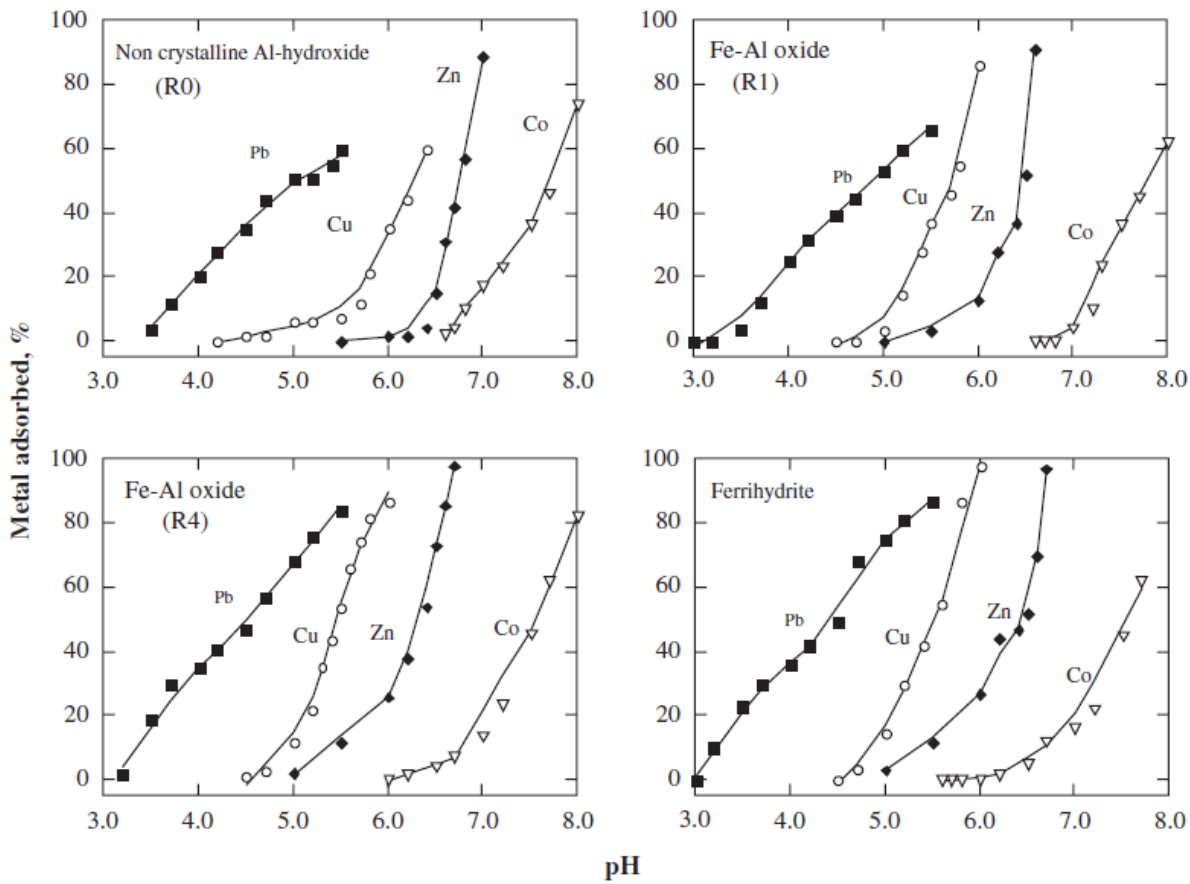

Figure 3. Adsorption of $\mathrm{Pb}, \mathrm{Cu}, \mathrm{Zn}$, and $\mathrm{Co}(\%)$ on noncrystalline Al-hydroxide (R0), mixed Fe-Al oxides (R1$\mathrm{R} 4)$ and ferrihydrite $(\mathrm{R} \infty)$ at different $\mathrm{pH}$ values $(50 \mathrm{mmol}$ of each metal per $\mathrm{kg}$ of oxide). Initial $\mathrm{Fe} / \mathrm{Al}$ molar ratio of 0 (R0), 1 (R1), 4 (R4), and $\infty(\mathrm{R} \infty)$.

Furthermore, the sorption capacity of an oxide is a function of its crystallinity, particle size and specific surface, as well as elemental composition (Colombo and Violante, 1996; Jackson, 1998; Violante and Pigna, 2002). Long term laboratory studies have demonstrated that $\mathrm{P}$ sorption onto noncrystalline Fe$\mathrm{Al}$ mixed hydroxides decreased with increasing $\mathrm{Fe} /$ Al molar ratio whereas that of $\mathrm{As}(\mathrm{V})$ increased. The sorption of $\mathrm{P}$ and $\mathrm{As}(\mathrm{V})$ was largely controlled by $\mathrm{Fe}$ and was more sensitive to $\mathrm{pH}$ change between 4.0 and 9.0 than pure $\mathrm{Fe}$ or $\mathrm{Al}$ hydroxides (Violante, unpublished data). Recently, Lu et al. (2013) studied the nature of noncrystalline nanoprecipitates obtained by coprecipitating $\mathrm{Al}$ and $\mathrm{Fe}$ or $\mathrm{Al}, \mathrm{Fe}$ and $\mathrm{Mn}$ and their capacity to sorb fluoride or $\mathrm{P}$.
Finally, Violante and Pigna (2002) and Violante et al. (2005) studied the competitiveness between $\mathrm{P}$ and $\mathrm{As}(\mathrm{V})$ when added as a mixture onto the mixed Fe-Al oxides aged 7 days at $20{ }^{\circ} \mathrm{C}$. In spite of the fact that $\mathrm{Fe}-\mathrm{Al}$ oxides had similar surface area $\left(200-285 \mathrm{~m}^{2} / \mathrm{g}\right)$ and mineralogy (ferrihydrite with different percentages of $\mathrm{Al}$ isomorphic substitution, as reported before), not only the total amount of $\mathrm{P}$ and $\mathrm{As}(\mathrm{V})$ sorbed on the oxides differed from samples to samples (usually decreased by decreasing $\mathrm{Al}$ in the oxides), but a variation in competitiveness was found. In fact, the sorbed $\mathrm{As}(\mathrm{V})$ /sorbed $\mathrm{P}$ molar ratio (r) values increased with increasing amounts of $\mathrm{Fe}$ present in the mixed gels. Arsenate and $\mathrm{P}$ sorption also increased with time. 


\section{Layered double hydroxides}

Many bivalent and trivalent cations may coprecipitate forming layered double hydroxides (LDHs). LDHs, also known as anionic clays, are a group of minerals with the general formula $\left[\mathrm{M}^{2+}{ }_{1-\mathrm{x}} \mathrm{M}^{3+}{ }_{\mathrm{x}}(\mathrm{OH})_{6}\right]^{\mathrm{x}}\left[\left(\mathrm{A}^{\mathrm{n}-}\right)\right.$ $\left.x / \mathrm{n} \mathrm{m} \mathrm{H} \mathrm{H}_{2}\right]^{\mathrm{x}}$, where $x$ is the molar ratio $\mathrm{M}^{3+} /\left(\mathrm{M}^{2+}+\right.$ $\left.\mathrm{M}^{3+}\right)$, taking values between 0.20 and 0.33 , while $\mathrm{M}^{2+}$ and $\mathrm{M}^{3+}$ are divalent $(\mathrm{Ca}, \mathrm{Mg}, \mathrm{Co}, \mathrm{Fe}, \mathrm{Cu}, \mathrm{Ni}, \mathrm{Mn})$ and trivalent metal cations ( $\mathrm{Al}, \mathrm{Fe}, \mathrm{Cr}$ ), respectively, and $\mathrm{A}$ is an interlayer anion (e.g., $\mathrm{Cl}, \mathrm{NO}_{3}, \mathrm{ClO}_{4}, \mathrm{CO}_{3}$, $\mathrm{SO}_{4}$ ) of valence $\mathrm{n}$. They are composed of positively charged brucite-like sheets and the positive charges are balanced by intercalation of anions in the hydrated interlayer regions, analogous to the cationic clays whose negative charge of the aluminosilicate layers are counterbalanced by cations (Violante et al., 2009a; Pigna et al., 2016).

The LDHs have relatively weak interlayer bonding and, as a consequence, the original anions sorbed in the interlayer are easily exchanged with many inorganic and organic anions by simple ion exchange methods. The use of LDHs as sorbents for the removal of inorganic and organic anions from waters have received considerable attention (Goh et al., 2008; Violante and Caporale, 2015). The formation of very well crystallized LDHs occurs few hours or days after the coprecipitation of bivalent and trivalent cations in alkaline environments. LDHs are present in natural environments. Green rusts, $\mathrm{Fe}^{2+} \mathrm{Fe}^{3+}-\mathrm{LDHs}$, are formed by a number of abiotic and biotic processes under circumneutral to alkaline conditions and have been identified in reductomorphic soils and groundwaters (Wang et al., 2010). Many studies have shown that metal cations [e.g. $\mathrm{Ni}^{2+}, \mathrm{Co}^{2+}, \mathrm{Zn}^{2+}$, $\mathrm{Cr}^{3+}$ and $\left.\mathrm{Fe}^{3+}\right]$ readily form $\mathrm{Me}^{2+} \mathrm{Al}-\mathrm{LDHs}$ when sorbed onto Al-oxides and Al-bearing phyllosilicates at $\mathrm{pH}>7.0$. Knowledge of parameters affecting formation, phase transformation, and reactivity of these precipitates are of paramount importance in soils and related environments.

As for other sorbents, such as Al- and Fe-oxides, Fe-Al mixed oxides (as discussed before), competitive sorption of $\mathrm{P}$ and $\mathrm{As}(\mathrm{V})$ or $\mathrm{As}(\mathrm{III})$ onto different LDHs, both in the absence or presence of foreign ligands has been considered in the last decade (Goh et al., 2008). For instance, Violante et al. (2009a) studied the sorption of $\mathrm{As}(\mathrm{V})$ on uncalcined and calcined (at $450{ }^{\circ} \mathrm{C}$ ) $\mathrm{Mg}$-Al layered double hydroxides (LDHs) containing chloride (LDH-Cl) or carbonate (LDHCO3) in the absence or presence of $P$. These authors found that more $\mathrm{P}$ than $\mathrm{As}(\mathrm{V})$ was removed by all the minerals but calcined LDH-Cl sorbed much lower amounts of both the anions than uncalcined LDH-Cl; on the contrary, calcined $\mathrm{LDH}-\mathrm{CO}_{3}$ showed a much greater capacity to sorb $\mathrm{As}(\mathrm{V})$ and $\mathrm{P}$ than uncalcined LDH-CO3. XRD diffractograms showed that As(V) was included into the interlayers of uncalcined LDH$\mathrm{Cl}$, but not in those of uncalcined $\mathrm{LDH}-\mathrm{CO}_{3}$. Competition in sorption between $\mathrm{As}(\mathrm{V})$ and $\mathrm{P}$ was affected by $\mathrm{pH}$, reaction time, surface coverage and sequence of addition of the anions. Phosphate showed a greater affinity for LDHs than As(V).

More recently, Caporale et al. (2011; 2013) studied the $\mathrm{As}(\mathrm{III})$ and $\mathrm{As}(\mathrm{V})$ removal capacity of Fe-based layered double hydroxides (i.e., $\mathrm{Mg}-\mathrm{Fe}-\mathrm{LDH}$ ), at varying $\mathrm{pHs}$, in presence of some LMMOLs (i.e., citrate, oxalate and tartrate) and inorganic anions (i.e., nitrate, nitrite, phosphate, selenite and sulfate). These authors found that Mg-Fe-LDH was able to sorb a much higher amount of As(V) than As(III), as well as they observed that the sorption of the former ion was much more $\mathrm{pH}$-dependent than the latter. This behavior might be related to the chemical properties of these two As species in solution at $\mathrm{pH}<9\left(\mathrm{H}_{2} \mathrm{AsO}_{4}{ }^{-}\right.$and $\mathrm{HAsO}_{4}{ }^{2-}$ ions vs. the uncharged $\mathrm{H}_{3} \mathrm{AsO}_{3}{ }^{0}$ ). They also noted that selected LMMOLs and inorganic ligands differently prevented the $\mathrm{As}(\mathrm{III})$ and $\mathrm{As}(\mathrm{V})$ sorption 
on $\mathrm{Mg}-\mathrm{Fe}-\mathrm{LDH}$; greater percentages of As(III) than As $(V)$ were replaced by the competing ligands, except $\mathrm{P}$. To describe the latter observation, Caporale et al. (2013) hypothesized that, when $\mathrm{P}$ was added to the $\mathrm{LDH}$ on which $\mathrm{As}(\mathrm{V})$ was previously sorbed, it competed with $\mathrm{As}(\mathrm{V})$ for common sites. Vice versa, since As(III) did not occupy all the sites occupied by As(V), P could be initially sorbed on empty sites easily accessible and only later P competed with As(III) for common sites.

Recently, Pigna et al. (2016) synthesized and characterized four different LDHs (i.e., Cu-Al-, Mg-Al-, $\mathrm{Mg}-\mathrm{Fe}-$, and $\mathrm{Zn}-\mathrm{Al}-\mathrm{LDH})$ in order to study their As(III) sorption capacity from contaminated waters, in the presence of inorganic anions commonly found in aquatic environments. They found that the less crystalline LDHs (i.e., Cu-Al-LDH and Mg-Fe$\mathrm{LDH}$ ) sorbed greater amounts of As(III) than the well-crystalline LDHs (i.e, Mg-Al-LDH and Zn-Al$\mathrm{LDH})$. The efficiency of the competing inorganic anions in inhibiting As(III) removal by all LDHs followed the increasing sequence: chloride $<$ fluoride $<$ sulfate $<<$ carbonate $<<$ phosphate, regardless of initial ligand/As(III) molar ratio (R) or LDH. These authors also assessed that, although $\mathrm{Cu}-\mathrm{Al}-\mathrm{LDH}$ sorbed lower amounts of As(III) than Mg-Fe-LDH, it showed a higher affinity for As(III).

\section{Coprecipitates of organic anions with hydrolytic products of $\mathrm{Al}$ and $\mathrm{Fe}$}

Many studies have been carried out on the formation, surface properties, mineralogy and reactivity of coprecipitates formed by the interaction of low molecular mass organic ligands (LMMOLs; e.g., oxalate, tartrate, citrate and tannate) with $\mathrm{Al}$ and/ or Fe hydrolytic products (Violante et al., 2003; 2007; 2010; Violante, 2013 and references there in). Strongly chelating organic ligands, which form stable complexes with $\mathrm{Al}$ and $\mathrm{Fe}$, strongly perturb $\mathrm{Al}$ and Fe hydrolytic reactions, retarding or completely inhibiting the crystallization of $\mathrm{Al}$ and $\mathrm{Fe}$ (oxy)hydroxides through occupation of $\mathrm{Al}$ and $\mathrm{Fe}$ coordination sites. The chemical composition, the molecular structure, and the nature of functional groups of each anion control the kinetic of crystallization of the metal oxides. The relative effectiveness of selected compounds in preventing the formation of well crystallized Al- or Fe-oxides promoting the formation of short-range ordered or noncrystalline precipitates is approximately as follows:

Acetate $<$ glutarate $<$ succinate $=$ phthalate $<$ glycine $<$ tricarballilate $<$ malonate $<$ acetylacetone $<$ glutamate $<$ aspartate $<$ oxalate $<$ salicylate $=$ malate $<$ tannate $<$ citrate $<$ tartrate.

Colombo et al. (2004) studied the influence of tannate (tannic acid/Al molar ratio [R] of 0.01-0.1), pH (from 5.0 to 8.0), and aging for many years at different temperatures on the nature, size of the particles and crystallinity of synthetic Al precipitation products. Electron microscope studies showed that some precipitates were noncrystalline materials even after a long aging period $\left(9\right.$ year at $\left.50^{\circ} \mathrm{C}\right)$ and usually appeared to be agglomerates of spherical particles whose size ranged from 10 to $40 \mathrm{~nm}$ (Figures $4 \mathrm{a}$ and $4 \mathrm{~b})$.

Other studies also demonstrated that the nature and concentration of organic ligands also affected the morphology of short-range ordered precipitates (Violante et al., 2002 and references there in). Short-range ordered Al-oxyhydroxides (poorly crystalline boehmite) also formed and showed fibrous morphology, but there were differences in the degree of fiber development depending on the ligand/Al molar ratio, $\mathrm{pH}$, time of aging and temperature (Figure $4 \mathrm{~b}$ ). These materials have large surface area and a great reactivity. 

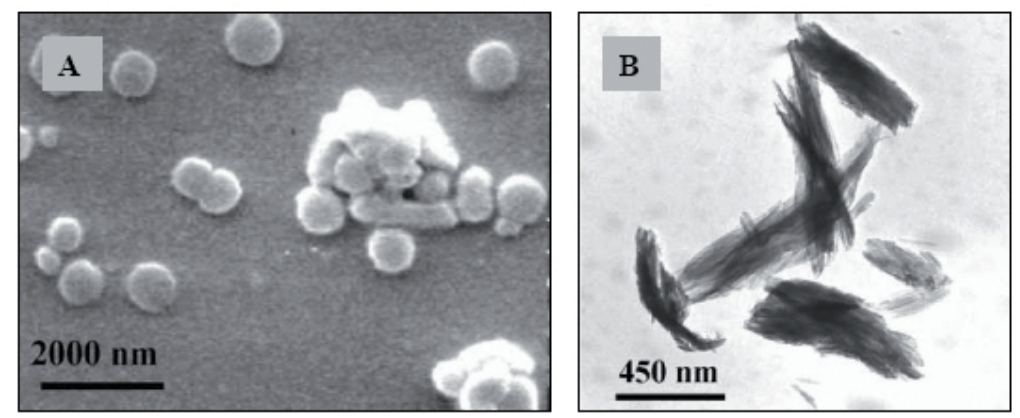

Figure 4. SEM (A) and TEM (B) of an $\mathrm{Al}(\mathrm{OH}) \mathrm{x}$-tannate coprecipitate formed at an initial tannate/ $\mathrm{Al}$ molar ratio of 0.01 obtained at $\mathrm{pH} 5.0$, aged for 10 months at $50^{\circ} \mathrm{C}$ and then for 5 years at room temperature (A) and after further aging for 3 days at $140{ }^{\circ} \mathrm{C}(\mathrm{B})$.

The role of LMMOLs present in the coprecipitates obtained by the interaction of organic ligands with $\mathrm{Al}$ and/or Fe species on the sorption of anions and cations received great attention in the last two decades. In soils, depending on the mechanisms of their interfering reactions, organic substances have a dual role of both hindering and promoting anion retention by the $\mathrm{Al}$ or $\mathrm{Fe}$ precipitation products. Maintenance of short-range structure of the coprecipitates with a large surface area by the presence of critical concentrations of LMMOLs helps to promote a high retention capacity of the coprecipitates if compared with $\mathrm{Al}$ or Fe oxides formed in absence of LMMOLs, characterized by the greater crystallinity and lower surface area, but the presence of organic ligands into the coprecipitates also prevents the sorption of nutrients and pollutants competing with them for sorption sites (Violante and Huang, 1989; Violante and Caporale, 2015). Many studies have demonstrated that the sorption of nutrients and pollutants onto LMMOLs$\mathrm{Al}$ (and/or Fe)-coprecipitates varied with the nature and amount of LMMOLs present into the samples and the affinity of the sorbate for the surfaces of the coprecipitates. Phosphate and As(V), which have a great affinity for $\mathrm{Al}$ and $\mathrm{Fe}$, are usually able to desorb, at least in part, the LMMOLs coprecipitated with $\mathrm{Al}$ or $\mathrm{Fe}$, so that $\mathrm{P}$ and $\mathrm{As}(\mathrm{V})$ sorption varies with the nature and amount of LMMOLs present in the coprecipitates (Violante and Caporale, 2015 and references there in).

De Cristofaro et al. (2000) found that hydroxyl-Aloxalate precipitates, containing different amounts of oxalate (OX), showed different chemical and physicochemical properties and reactivity toward $\mathrm{P}$ (Table 2). The quantities of P sorbed on the hydroxyl-Aloxalate coprecipitates were related either to the amount of oxalate coprecipitated with $\mathrm{Al}$ or to the specific surface. In fact, it was found that the greater the oxalate content in the precipitates, the higher were the specific surface and reactivity of the solids. Phosphate sorption on the hydroxyl-Al-oxalate precipitates that contained greater amounts of oxalate 
$[\mathrm{Al}(\mathrm{OH}) \mathrm{OX} 5]$ remained nearly constant in the range of $\mathrm{pH} 4.0-8.0$, probably due to the release of oxalate from the surfaces of the samples with increasing $\mathrm{pH}$ and formation of new sorption sites (Table 2). These authors also showed that relatively high amounts of oxalate were released from the hydroxyl-Al-oxalate precipitates by $\mathrm{P}$, and, of course, much more from the complexes containing higher amounts of oxalate (Table 2). At alkaline pHs, much greater percentage of oxalate, relative to the total content of oxalate coprecipitated with $\mathrm{Al}$ in the solids, was released from the solids containing greater amounts of the organic anion. These results may be explained by considering that the higher the amounts of oxalate initially coprecipitated with $\mathrm{Al}$, the greater the percentage of oxalate present in the external surfaces of the samples. In other words, the $\mathrm{Al}(\mathrm{OH}) \mathrm{x}$-oxalate samples with a lower organic molecule content [e.g. $\mathrm{Al}(\mathrm{OH})$ OX1] had greater amounts of oxalate present within the network of the organo-mineral complexes, where the organic ligands were much more protected and not easily replaced by $\mathrm{P}$ and $\mathrm{OH}-$ ions.

Table 2. Amounts of phosphate $(\mathrm{P})$ sorbed $\left(1000 \mathrm{mmol} \mathrm{P}\right.$ added $\left.\mathrm{kg}^{-1}\right)$ and oxalate $(\mathrm{OX})$ released at different $\mathrm{pH}$ values on/from the aluminum precipitation products formed at $\mathrm{pH} 7.0$ in the presence of different initial oxalic acid (OX)/Al molar ratios $(\mathrm{R})^{*}$

\begin{tabular}{|c|c|c|c|c|}
\hline \multirow[t]{2}{*}{$\mathrm{pH}$} & $\begin{array}{l}\text { OX released in } \\
\text { the absence of } P\end{array}$ & P sorbed & $\begin{array}{l}\text { OX released in } \\
\text { the presence of } \mathrm{P}\end{array}$ & $\mathrm{R}_{\mathrm{p}}$ \\
\hline & \multicolumn{4}{|c|}{$\mathrm{mM} \mathrm{kg}^{-1}$} \\
\hline $\mathrm{Al}(\mathrm{OH}) \mathrm{OX} 1^{*}$ & $($ S.A. 200)** & & & \\
\hline 4.0 & $45(<5)$ & 105 & $45(<5)$ & --- \\
\hline 6.0 & $65(7)$ & 105 & $75(8)$ & 0.10 \\
\hline 8.0 & $90(7)$ & 85 & $110(11)$ & 0.23 \\
\hline $\mathrm{Al}(\mathrm{OH}) \mathrm{OX} 2^{*}$ & $(\text { S.A. } 465)^{* *}$ & & & \\
\hline 4.0 & $175(11)$ & 716 & $163(10)$ & --- \\
\hline 6.0 & $60(<5)$ & 590 & $210(13)$ & 0.25 \\
\hline 8.0 & 435 (27) & 490 & $520(33)$ & 0.17 \\
\hline $\mathrm{Al}(\mathrm{OH}) \mathrm{OX} 5^{*}$ & $($ S.A. 698)** & & & \\
\hline 4.0 & $1230(46)$ & 950 & $1185(44)$ & --- \\
\hline 6.0 & 490 (18) & 945 & $1180(44)$ & 0.73 \\
\hline 8.0 & $1300(48)$ & 955 & $1920(72)$ & 0.65 \\
\hline
\end{tabular}

${ }^{*} \mathrm{Al}(\mathrm{OH}) \mathrm{OX} 1: \mathrm{R}=0.1 ; \mathrm{Al}(\mathrm{OH}) \mathrm{OX} 2: \mathrm{R}=0.2 ; \mathrm{Al}(\mathrm{OH}) \mathrm{OX} 5: \mathrm{R}=0.5$.

${ }^{* *}$ S.A. Surface Area

Values in parenthesis are the percentage of OX released by the Al-OH-OX precipitates relative to the total content of OX precipitated. 


\section{Coprecipitates of inorganic anions with hydrolytic products of $\mathrm{Al}$ and $\mathrm{Fe}$}

Coprecipitates obtained by the interaction of inorganic anions, both nutrients (e.g. P and S) and pollutants [arsenate, arsenite, antimonate] with $\mathrm{Al}$ and/or Fe also received attention.

The formation of basic $\mathrm{Al}$ sulfate minerals in the mineral horizons of Spodosols is involved in the retention of $\mathrm{S}$. The precipitation of hydroxyl $\mathrm{Al}$ sulfates can be promoted by applying gypsum as an ameliorant for acid subsoils. Many authors have demonstrated that $\mathrm{S}$ is readily replaced by $\mathrm{P}$ when sorbed on variable charge minerals or soils (Violante et al., 1996 and references there in). Violante et al. (1996) studied the sorption of $\mathrm{P}$ and oxalate on a synthetic Al-hydroxy-sulfate coprecipitate and the associated release of $\mathrm{S}$ from the complex. The sample was noncrystalline to XRD and contained $1.35 \mathrm{~mol} \mathrm{~S}, 11.9 \mathrm{~mol} \mathrm{Al}$ and only $21 \mathrm{mmol} \mathrm{K}$ per kg of the precipitate (Figure 5). Much more P than oxalate was sorbed, but in most cases oxalate caused more removal of S than did P (Figure 5). Sulfate was only partly removed from the coprecipitate even after repeated washings with $\mathrm{P}$ or oxalate. Many factors seem to bear on the sorption of $\mathrm{P}$ and oxalate and the removal of S from the Al-hydroxy-sulfate coprecipitate: i) the affinity of the ligands for the surfaces of the coprecipitate and the capacity of each anion $(\mathrm{OH}-$ included) to replace S; ii) the solubilisation of the complex, mainly in acid environments and in the presence of oxalate; iii) the presence of S either on the external surfaces (easily replaced by the other anions) or in the network of the coprecipitate. These results seem to strengthen the old hypothesis that $\mathrm{S}$ sorbed on the surface groups of hydrous oxides is desorbed whereas $\mathrm{S}$ that penetrates into some amorphous region of the crystal surface is retained. The absence or presence of $\mathrm{S}$ in coprecipitates in soils may explain why some scientists could replace large amounts of $\mathrm{S}$, whereas others found that extractions with $\mathrm{KH}_{2} \mathrm{PO}_{4}$ did not remove all the $\mathrm{S}$ present in latosols and brown forest soils (Violante et al., 1996 and references there in).
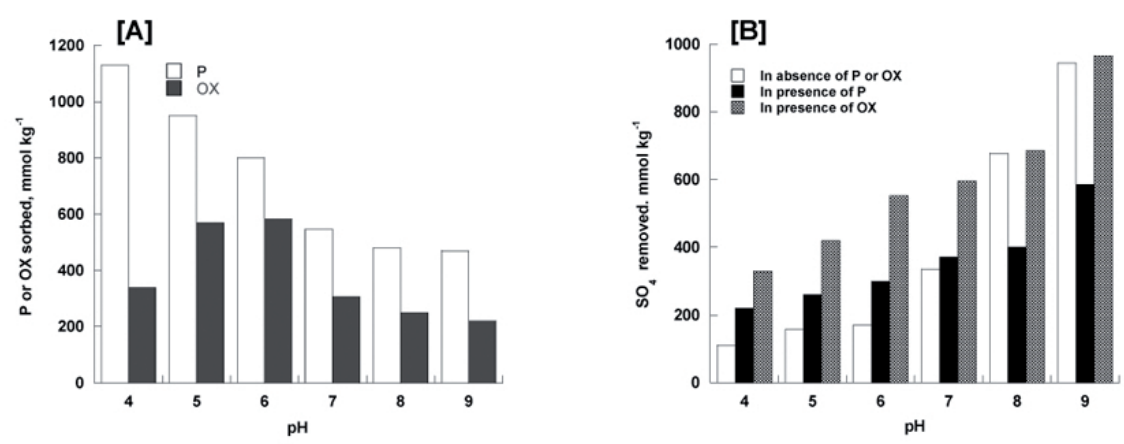

Figure 5. Amounts of phosphate $(\mathrm{P})$ and oxalate $(\mathrm{OX})$ sorbed on [A], and of sulphate $\left(\mathrm{SO}_{4}\right)$ removed from [B], on $\mathrm{Al}(\mathrm{OH}) \mathrm{x}-\mathrm{SO}_{4}$ coprecipitate at different $\mathrm{pHs}$, when none, $1500 \mathrm{mmol}$ of $\mathrm{P}$ per $\mathrm{kg}$ or $1500 \mathrm{mmol}$ of OX per $\mathrm{kg}$ were added. The coprecipitate contained $1.35 \mathrm{~mol} \mathrm{SO}_{4}, 11.9 \mathrm{~mol} \mathrm{Al}$ and $21 \mathrm{mmol} \mathrm{K} \mathrm{per} \mathrm{kg.}$ 
Phosphate is very easily coprecipitated with $\mathrm{Al}$ and/ or Fe hydrolytic species in soils (Violante et al., 2002 and references there in). Studies on the sorption of organic and inorganic ligands on $\mathrm{Al}(\mathrm{Fe}-) \mathrm{OHx}$-phosphate coprecipitates received negligible attention. Violante and Gianfreda (1995) studied the sorption of selected LMMOLs on a $\mathrm{Al}(\mathrm{OH}) \mathrm{x}-\mathrm{P}$ complex formed by coprecipitating at $\mathrm{pH} 8.2 \mathrm{P}$ in the presence of $\mathrm{Al}(\mathrm{P} / \mathrm{Al}$ molar ratio 0.1$)$. This noncrystalline sample showed a surface area of $350 \mathrm{~m} 2 / \mathrm{g}$ and $850 \mathrm{mmol} / \mathrm{kg}$ of P. More P than oxalate, succinate, malate was sorbed on this sample, indicating that many other sites were free and specific for P. Surprisingly, the LMMOLs were able to remove only negligible quantities of $\mathrm{P}$. These findings appear to be in contrast with the results obtained by many authors (Jara et al., 2006; Violante, 2013) that strong chelating ligands [oxalate, citrate, malate, arsenate] when added on variable charge minerals after $\mathrm{P}$, partially reduced $P$ sorption particularly in acidic environments. These findings deserve an explanation. Indeed, P ions coprecipitated with $\mathrm{Al}$ could be present in the structural network of the sample. Consequently, many P ions could be more protected and not easily replaced. Furthermore, $\mathrm{P}$ anions sorbed onto the external surfaces of the oxide may be occluded because of aggregation of the aluminous particles after drying and, mainly, may decrease the surface charge of the oxide preventing the sorption of foreign anions. Finally, P anions initially coprecipitated may form with time stronger inner-sphere complexes or new precipitates also on the external surfaces, resulting less mobile (Sparks, 2003; Borda and Sparks, 2008; Violante, 2013).

In soil environments also toxic elements in anionic forms (e.g. arsenic, antimony, molibdate) may be coprecipitated with hydrolytic species of $\mathrm{Al}$ and $\mathrm{Fe}$. Some studies were carried out by Violante and coworkers on coprecipitates obtained by precipitating $\mathrm{As}(\mathrm{V})$ with $\mathrm{Al}$ and/or Fe. Violante et al. (2006, 2007, 2009b) evidenced that the mineralogy, the sur- face properties and chemical composition of the Al$\mathrm{As}(\mathrm{V})$ or $\mathrm{Fe}-\mathrm{As}(\mathrm{V})$ coprecipitates were affected by the initial $\mathrm{pH}$, initial $\mathrm{As} / \mathrm{Al}(\mathrm{Fe})$ molar ratio (R) and aging. These authors demonstrated that less As(V) was replaced by $\mathrm{P}$ from $\mathrm{As}(\mathrm{V})$ iron and/or aluminum coprecipitates than from previously formed iron and/ or aluminum oxides on which $\mathrm{As}(\mathrm{V})$ was sorbed. XPS analyses performed on the samples formed at $\mathrm{R}$ $=0.1$ and $\mathrm{pH} 7.0$ obtained by coprecipitating Fe and $\mathrm{As}(\mathrm{V})$ (7FeR0.1) by adding As(V) immediately after the precipitation of $\mathrm{Fe}$ (7FeAR0.1), before and after the addition of $\mathrm{P}$ evidenced that $\mathrm{P}$ removed more arsenic $(\sim 25 \%)$ from the surfaces of the sample where As was added (7FeAR0.1), compared to the sample where $\mathrm{As}(\mathrm{V})$ was coprecipitated with $\mathrm{Fe}(\sim 5 \% \mathrm{As}(\mathrm{V})$ removed; 7FeR0.1).

Low amounts of $\mathrm{As}(\mathrm{V})$ coprecipitated with aluminum and/or iron oxides at $\mathrm{pH} 7.0$ were removed by $\mathrm{P}$ (5-25 $\%$ ), attributed to the formation of strong inner-sphere complexes, metal- $\mathrm{As}(\mathrm{V})$ precipitates, and partial occlusion of $\mathrm{As}(\mathrm{V})$ into the coprecipitates. A comparison of the desorption of $\mathrm{As}(\mathrm{V})$ by $\mathrm{P}$ from $\mathrm{Al}-\mathrm{As}(\mathrm{V})$, $\mathrm{Fe}-\mathrm{As}(\mathrm{V})$, and $\mathrm{Fe}-\mathrm{Al}-\mathrm{As}(\mathrm{V})$ coprecipitates evidenced that $\mathrm{P}$ desorbed more $\mathrm{As}(\mathrm{V})$ from $\mathrm{Al}-\mathrm{As}(\mathrm{V})$, $\mathrm{Fe}-\mathrm{Al}-\mathrm{As}(\mathrm{V})$ than $\mathrm{Fe}-\mathrm{As}(\mathrm{V})$ coprecipitates (in the order listed), because $\mathrm{As}(\mathrm{V})$ forms stronger complexes with Fe than with Al.

The formation of Fe-As(III) coprecipitates may occur in natural environments, particularly under anoxic conditions encountered in reducing groundwaters or flooded rice fields whose dissolved Fe(II) is often present in high concentrations. When oxidizing conditions are restored, the precipitation of Fe hydroxide flocks may scavange As from aqueous solutions, with the formation of Fe-As(II,III) coprecipitates. Zanzo et al. (2017 and references there in) found that the presence of As(III) during Fe(II) oxidation or by coprecipitating $\mathrm{As}(\mathrm{III})$ with $\mathrm{Fe}(\mathrm{III})$ results in the formation of noncrystalline phases composed of nanosized clusters. 
The findings obtained by Zanzo et al. (2017) are in line with the results on $\mathrm{As}(\mathrm{V})$ coprecipitation with iron obtained by Violante et al. (2007), who showed that aging generally leads to the formation of more ordinate structures for pure Fe(hydr)oxides, while increasing amounts of As appear to promote the formation and long-term stabilization of shorter-range order Fe-As(III,V) coprecipitates. Zanzo et al. (2017) also studied the potential extraction of As(III) and As(V) from $\mathrm{Fe}-\mathrm{As}(\mathrm{III})$ coprecipitates by different organic and inorganic ligands and showed that their efficiency increased in the order: silicate $\leq$ chloride $<$ inositholhexaphosphate $<$ citrate $<$ phosphate.

Mitsunobu et al. (2010) studied the structures of $\mathrm{Sb}(\mathrm{V})$ species in synthetic $\mathrm{Sb}(\mathrm{V})$-coprecipitate and sorbed ferrihydrite and goethite at different $\mathrm{Sb} / \mathrm{Fe}$ molar ratios by X-ray absorption fine structure (EXAFS) analyses. EXAFS analyses evidenced the formation of inner-sphere surface complex when $\mathrm{Sb}(\mathrm{V})$ was sorbed on ferrihydrite and goethite. When coprecipitated $\mathrm{Sb}(\mathrm{V})$ was incorporated into the iron oxides. The incorporation of $\mathrm{Sb}(\mathrm{V})$ was also confirmed in natural $\mathrm{Fe}(\mathrm{III})$-oxyhydroxides in contaminated soil. These authors evidenced by EXAFS analyses that $\mathrm{Sb}(\mathrm{V})$ was structurally incorporated into goethite and/or hematite formed by initial two-line ferrihydrite containing coprecipitated $\mathrm{Sb}(\mathrm{V})$.

\section{Coprecipitation of anions with $\mathrm{Al}$ and $\mathrm{Mg}$ in the formation of LDHs}

Many organic ligands or molecules, such as aminoacids, oligopeptides, aromatic acids, and enzymes, have been intercalated in LDHs by co-precipitating them with $\mathrm{Mg}$ and $\mathrm{Al}$ (or other bivalent or trivalent cations). However, the synthesis, mineralogy and surface properties of layered double hydroxides obtained by co-precipitating inorganic and organic ligands, with a strong affinity for Al has received little attention. Prasanna and Vishnu-Kamath (2009) found that the XRD pattern of co-precipitated MgAlAs(V)-LDH showed only 4 broad and asymmetric peaks due to structural disorder. Recently, Sommella et al. (2015) investigated the nature and reactivity of $\mathrm{Mg}-\mathrm{Al}-\mathrm{As}(\mathrm{V}) \mathrm{LDHs}$ formed in solution affected by As content, $\mathrm{pH}$, aging. The authors demonstrated that co-precipitation of $\mathrm{Al}, \mathrm{Mg}$ and $\mathrm{As}(\mathrm{V})$ promoted the concomitant formation of different precipitates (mainly LDHs and metal oxides), whose nature, mineralogy, chemical composition and reactivity were affected by initial $\mathrm{R}$, aging, $\mathrm{pH}$, and temperature. At the beginning, very poorly crystalline LDHs, whose crystals were extremely distorted and small in size, as well as noncrystalline or short-range ordered $\mathrm{Al}(\mathrm{Mg})$-oxides, were formed. The presence of $\mathrm{As}(\mathrm{V})$ anions certainly perturbed or even inhibited the formation of LDHs and facilitated the formation of noncrystalline $\mathrm{Al}(\mathrm{Mg})$-oxides. During the aging process the LDH crystals increased in quantity, size, and order, whereas $\mathrm{Al} / \mathrm{Mg}$ oxide content decreased, being probably converted by solubilization and re-crystallization into LDH materials (see Sommella et al., 2015 their Scheme 1). In fact, prolonged aging of the samples (mainly at $50-70{ }^{\circ} \mathrm{C}$ ) promoted the crystallization of LDHs, whose XRD peaks became relatively stronger and/or visible but still broad and asymmetric. X-ray absorption spectroscopy (XAS) data confirmed that with aging, As chemical environment became more crystalline due to a larger formation of LDH crystals and revealed that the surface area, chemical composition and reactivity of the precipitates were also influenced by $\mathrm{pH}$ of synthesis, aging and initial As concentration. It has been demonstrated that during the aging process Al- and/or Mg-oxides were probably transformed by dissolution/re-precipitation processes into LDHs more crystalline but still defective LDHs. The sorption of $P$ decreased with aging of the samples, whereas the subsequent $\mathrm{As}(\mathrm{V})$ removal increased. The distribution of $\mathrm{As}(\mathrm{V})$ in the precipitates also changed with aging. 
This work also demonstrated that (i) As(V) (as well as other anions with strong affinity for $\mathrm{Al}$ ) retards or inhibits the formation and transformation of LDHs and (ii) more $\mathrm{As}(\mathrm{V})$ is removed from solution if coprecipitated with $\mathrm{Al}$ and $\mathrm{Mg}$ than by sorption onto well crystallized LDHs.

\section{Interactions of hydroxyl-Al and -Fe species with phyllosilicates (Binary complexes)}

The first researches on the formation of synthetic complexes between soil components were mostly devoted to the interaction between expandable clay minerals and $\mathrm{OH}-\mathrm{Al}$ or $\mathrm{OH}-\mathrm{Fe}$ species (both solid and soluble) with the formation of hydroxyl-interlayered vermiculite and smectite (chlorite-like complexes) or between phyllosilicates or variable charge minerals (mostly metal oxides) with humic and fulvic acids, other organic compounds and biomolecules (e.g. enzymes, carbohydrates) and microorganisms, with the formation of binary complexes (Violante and Gianfreda, 2000; Yuan and Theng, 2013 and references there in). At $\mathrm{pH}$ values, usually recognized in soils, interactions between the positively charged $\mathrm{OH}-\mathrm{Al}$ (and/or $-\mathrm{Fe}$ ) species and negatively charged phyllosilicates occurs easily. Hydroxy-Al (-Fe)-clay complexes, resembling hydroxyl-interlayered smectite and vermiculite in soils can be synthesized by neutralizing Al and $\mathrm{Fe}$ ions in clay suspensions or by mixing $\mathrm{OH}-\mathrm{Al}$ (-Fe) polymers or noncrystalline oxides with clays. It has been established that, depending on the cation exchange capacity (C.E.C.), specific surface and charge density of the clay, variable quantities of noncrystalline hydrous $\mathrm{Al}$ (or Fe) gel can be sorbed between the lattice layers of expandable clays. The greater reduction on swelling or dispersion by $\mathrm{Al}$ rather than $\mathrm{Fe}$ interlayer components is presumably related to the more uniform distribution of the former within the interlayer space and so to the greater stability of $\mathrm{Al}$ interlayer compounds. In the presence of lesser amounts of $\mathrm{Al}$ oxides (usually quantities lower than 500-800 mequivalent/100 g) the formation of $\mathrm{Al}(\mathrm{OH})_{3}$ polymorphs is inhibited or much delayed, particularly in acid conditions (antigibbsite effect). In fact in samples with 400-800 mequivalent of $\mathrm{Al}$ species per $100 \mathrm{~g}$ of clay, spheroidal particles attributable to noncrystalline $\mathrm{Al}$ precipitates were observed on the clay surfaces under the electron microscope even after 14 months of aging. In contrast, when a large amount of Al-gel was precipitated on the surfaces of montmorillonite particles, a gradual but continuous crystallization sets in to form gibbsite, bayerite and/ or nordstrandite $\left[\mathrm{Al}(\mathrm{OH})_{3}\right.$ polymorphs].

The influence of complexing ligands on $\mathrm{Al}$ interlayer formation and stability has also received attention, as discussed below (Violante et al., 1998).

\section{Formation and properties of ternary complexes [OH-Al(-Fe)-organic ligands-phyllosilicates com- plexes]}

Organic ligands and humic and fulvic acids are sorbed on the surfaces of phyllosilicates or intercalated into the interlayers of expandable clays only at low $\mathrm{pH}$ values (say $\mathrm{pH}<5$ ), where the degree of dissociation is very low. However, once $\mathrm{OH}-\mathrm{Al}$ (or - $\mathrm{Fe}$ ) species interact with organic acids to form $\mathrm{OH}-\mathrm{Al}(-\mathrm{Fe})$-organic ligand complexes, the sorption of these complexes on the external surfaces of clays or in the interlayers of expandable phyllosilicates (mostly montmorillonite) can take place if the net attractive forces between the positively charged sites of the complexes and negatively charged clay surfaces can overcame the repulsive forces between the anionic ligands of the complexes and clay surfaces and any steric hindrance that may be present. Goh and Huang (1986) demonstrated that at citrate or tannate/Al molar ratio $<0.1$, the formation of well oriented $\mathrm{OH}-\mathrm{Al}$ complexes in montmorillonite was not 
prevented. Only at citric acid/Al molar ratio higher than 0.3 the sorption of $\mathrm{Al}$ was drastically reduced or prevented.

As reported before, the presence of organic ligands strongly stabilizes the formation of $\mathrm{Al}(\mathrm{OH}) \mathrm{x}$ polymorphs even in alkaline solutions. Violante et al. (1993; 1999) demonstrated that in the absence of montmorillonite noncrystalline materials were found after 7-10 years of aging in samples formed in the presence of tartrate, citrate, and tannate at $\mathrm{pH} \leq 8.0$ and at ligand/Al molar ratio $(\mathrm{R})$ ranging from 0.05 to 01 ; these noncrystalline coprecipitates were found in the presence of malate and $\mathrm{P}$ at $\mathrm{R}$ from 0.1 to 0.5 . Very poorly crystalline and strongly distorted Al-oxyhydroxides (particle size $<1000 \mathrm{~nm}$ ) were found in suspension within a wide range of $\mathrm{pH}(6.0-11.0)$ in the presence of tannate, malate, salicylate even after more than 20 years (Violante, unpublished data). In contrast, montmorillonite promoted the formation of gibbsite, but some samples synthesized at $\mathrm{pH} \leq 6.0$ in the presence of citrate or tartrate $(\mathrm{R}=0.1)$ or tannate $(\mathrm{R}=0.02$ or 0.1$)$ showed after 6 years of aging interstratification of $\mathrm{OH}-\mathrm{Al}$ species in the interlayers of montmorillonite and complete lack of $\mathrm{Al}(\mathrm{OH})_{3}$ polymorphs. In Figure 6 are reported the X-ray diffraction patterns of $\mathrm{Al}(\mathrm{OH}) \mathrm{x}$-montmorillonite complexes formed at $\mathrm{pH} 6.0$ in the absence and presence of citric $(\mathrm{R}=0.1)$ or tannic acid $(\mathrm{R}=0.02$ and 0.1$)$. The complexes obtained in the absence of organic ligands showed formation of gibbsite $(4.87 \AA)$ and a partial interstratifications of aluminous materials (14.01 A vs $12.45 \mathrm{~A}$ at $25^{\circ} \mathrm{C}$ ). On the contrary, the complexes formed in the presence of organic ligands showed complete absence of gibbsite after 6 years of aging and a much greater interstratifications (15.08-16.17 $\AA$ ). As reviewed by Violante and Caporale (2015) interactions of $\mathrm{OH}-\mathrm{Al}(-\mathrm{Fe})$ species and LMMOAs or large organic ligands (humic, fulvic acids and biopolymers, e.g. proteins) promote the formation of complexes with different size, shape and charge. Many studies also demonstrated that the distribution on the external surface and in the interlayer space of montmorillonite of OH-Al-organic complexes was a consequence of how the component reacted each other.

Buondonno et al. (1989) and Violante et al. (1999) studied the effect of the sequence of addition of montmorillonite, $\mathrm{OH}-\mathrm{Al}$ ions, and tannic or humic acids on the nature of the complexes formed at $\mathrm{pH}$ 4.5 or 7.0. A negligible amount of tannate was fixed on the surfaces of montmorillonite in the absence of $\mathrm{Al}$, whereas in the presence of $\mathrm{Al}, \mathrm{OH}-\mathrm{Al}$-tannate species were sorbed on clay surfaces.
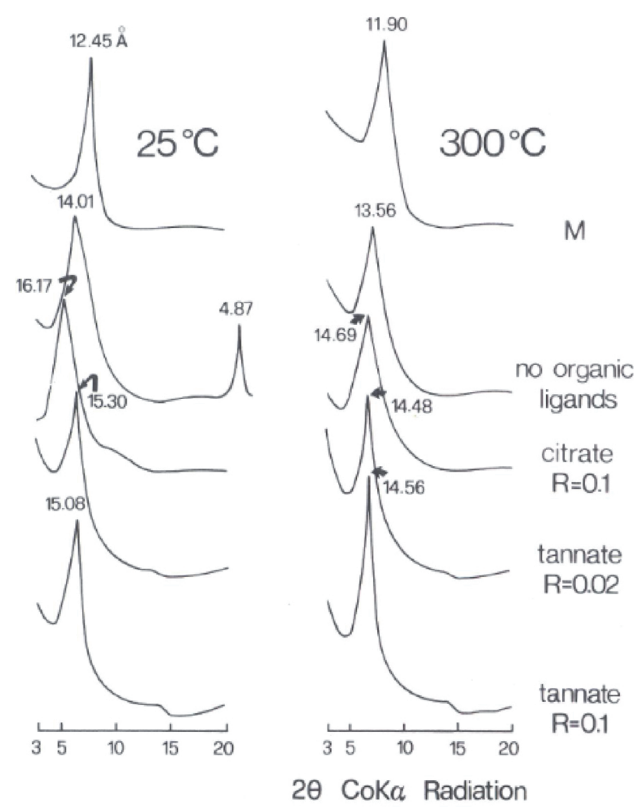

Figure 6. X-ray powder diffractograms of montmorillonite $(\mathrm{M})$ and chlorite-like complexes (16 meq $\mathrm{Al} / \mathrm{g}$ of montmorillonite) formed at $\mathrm{pH} 6.0$ in the absence or in the presence of citrate $(\mathrm{R}=0.1)$ and tannate $(\mathrm{R}=0.02$ and 0.10$)$ after 6 years of aging (reprinted from Violante et al., 1993). 
Their distribution on the external surface and in the interlayer space of montmorillonite was a consequence of how the components reacted each other (Buondonno et al., 1989). The organo-mineral complexes showed broad peaks ranging from $1.560 \mathrm{~nm}$ when montmorillonite (M), OH-Al (A) and tannic acid $(\mathrm{T})$ were mixed together (AMT), to 1.920 when
$\mathrm{OH}-\mathrm{Al}$ species were added to a mixture of montmorillonite and tannic acid (A+MT). The organomineral complexes showed different behavior to preheating, ethylene glycol salvation and chemical treatment. These authors also showed distinct differences in cation exchange capacity (CEC), carbon content, extractable $\mathrm{Al}$ and mode of aggregation (Figure 7).
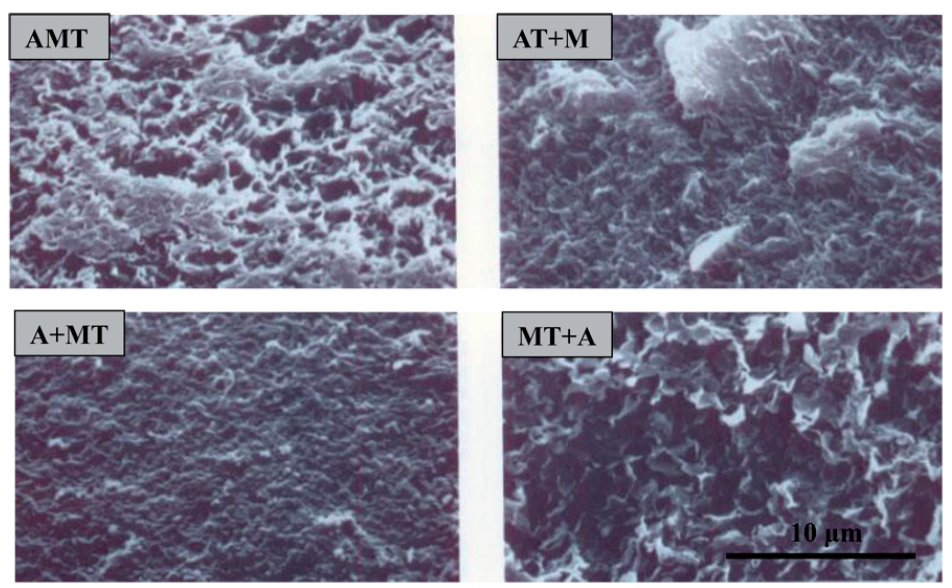

Figure 7. Scanning electron micrographs of the complexes AMT [simultaneous mixing of aluminum (A), montmorillonite (M) and tannic acid (T)], AT $+\mathrm{M}, \mathrm{A}+\mathrm{MT}$ and $\mathrm{MT}+\mathrm{A}$ (addition of the last component 2 hour late the formers).

Later, Buondonno and Violante (1991) also demonstrated that the titratable acidity values of $\mathrm{OH}-\mathrm{Al}-$ tannate-montmorillonite complexes formed at $\mathrm{pH}$ 4.5 were affected by 1 ) the addition sequence of the components, 2) the feed rate of the base and the absence or presence of neutral salts (acidity values in $\mathrm{CaCl}_{2}$ substantially higher than those determined in $\mathrm{KCl}$ or water), 3) the drying of the samples (freezedried or air-dried), 4) the sonification (Table 3). The complexes showed acidity values in $\mathrm{CaCl}_{2}$ substantially higher than those determined in $\mathrm{KCl}$ or in water (in the order listed), probably because many weak acidic groups released $\mathrm{H}^{+}$ions by complexation (tannate molecules) or sorption ( $\mathrm{OH}-\mathrm{Al}$ species) of
$\mathrm{Ca}^{2+}$ ions. The hydroxyl-Al-tannate-montmorillonite complexes, which were washed differently (dialyzed or ultrafiltered) and dried (freze-dried or air-dried) also showed remarkably different titratable acidity. All the complexes usually showed much lower acidity values when air-dried than when freezedried. After sonification the titratable acidity values of all the complexes increased, but some air-dried samples, even after four sonification treatments, showed titratable acidity lower than that of the same freeze-dried complexes before sonification (Table 3). Clearly, the different nature and distribution of the OH-Al-tannate ions promoted different aggregation of the particles after drying. 
The stability and strength of the aggregates drastically inhibited a complete neutralization reaction of the acidic sites. In other words, the stronger the aggregation of the particles, the lower the titrable acidity value. Indeed, electron optical observation showed that all the freeze-dried complexes were characterized by different morphology, state of aggregation, surface area and porosity (Table 3; Figure 7). The $\mathrm{AT}+\mathrm{M}$ and $\mathrm{A}+\mathrm{MT}$ complexes, which showed after drying the lowest titratable acidity values (Table 3 ), appeared to be more aggregated than the complexes $\mathrm{AMT}$ and $\mathrm{MT}+\mathrm{A})$ (Figure 7), which showed higher titratable acidity values (Table 3 ).
De Cristofaro and Violante (2001) also demonstrated that the complexes obtained by coprecipitating $\mathrm{OH}-$ Al species, montmorillonite and a protein (albumin) showed different intercalation of albumin into the interlayer of the expandable clays.

Many studies have been carried out on the interactions of selected enzymes (urease, phosphatase, invertase) with clay minerals, $\mathrm{OH}-\mathrm{Al}$ species and/or organic substances and on their residual activity (as reviewed by Violante and Gianfreda, 2000).

The interaction among clay minerals, metal oxides and microorganisms also received great attention.

Table 3. Titratable acidity of the undisturbated suspensions and of dialyzed and freeze-dried samples titrated to pH 8.0 by $0.05 \mathrm{M} \mathrm{NaOH}$ in $\mathrm{H}_{2} \mathrm{O}, 1 \mathrm{M} \mathrm{KCl}$ or $0.5 \mathrm{M} \mathrm{CaCl}_{2}$.

\begin{tabular}{cccccc} 
Sample & \multicolumn{3}{c}{$\begin{array}{c}\text { Suspensions titrated in } \\
(\mathrm{meq} / \mathrm{L})\end{array}$} & \multicolumn{3}{c}{$\begin{array}{c}\text { Solid phases titrated in } \\
(\mathrm{meq} / \mathrm{L})\end{array}$} \\
\cline { 2 - 6 } & $\mathrm{H}_{2} \mathrm{O}$ & $\mathrm{KCl}$ & $\mathrm{CaCl}_{2}$ & $\mathrm{H}_{2} \mathrm{O}$ & $\mathrm{KCl}$ \\
\hline $\mathrm{A}$ & 16.6 & 15.5 & 16.3 & --- & --- \\
$\mathrm{T}$ & 4.4 & 4.9 & 10.5 & --- & --- \\
$\mathrm{AT}$ & 6.9 & 9.8 & 15.3 & 5.5 & 25.5 \\
$\mathrm{AM}$ & 11.5 & 11.8 & 14.2 & 14.6 & 13.8 \\
$\mathrm{AMT}$ & 4.7 & 8.1 & 13.6 & 13.0 & 75.4 \\
$\mathrm{AM}+\mathrm{T}$ & 5.7 & 8.5 & 14.0 & 20.0 & 92.5 \\
$\mathrm{AT}+\mathrm{M}$ & 5.0 & 8.6 & 15.0 & 1.5 & 7.0 \\
$\mathrm{MT}+\mathrm{A}$ & 5.5 & 9.2 & --- & 9.5 & 70.5 \\
$\mathrm{~A}+\mathrm{MT}$ & 6.5 & 10.3 & --- & 3.5 & 16.5 \\
Average error & 2.2 & 1.9 & $<2.5$ & 2.9 & 2.0 \\
$(\%)$ & & & & & \\
\hline
\end{tabular}

$\mathrm{A}=$ hydroxyl-Al ions; $\mathrm{T}=$ tannic acid; $\mathrm{M}=$ montmorillonite; The samples were prepared by different sequence of addition of these three components. 


\section{Stabilization of organic substances in organo-min- eral coprecipitates and soils}

An important mode of bonding of organic ligand and inorganic soil components is ligand exchange between the carboxylic groups (mainly) of organic molecules (both LMMOLs and humic and fulvic acids) and surface hydroxyl groups of clay minerals and Aland/or Fe-oxides.

As summarized by Yuan and Theng (2013) very strong sorption of humic and fulvic acids on inorganic clays occurs in Andisols when nanosize minerals as allophanes, imogolite and Fe-oxides present a large concentration of surface hydroxyl groups. As a consequence, the strong binding of organic matter onto allophanic surfaces confer great stability on humic substances. It has been demonstrated that after 20 years of cropping the Andisols accumulated a quantity of organic carbon twice that of Inceptisol (containing mainly mica as clay mineral), but lost $10 \mathrm{~T} \mathrm{ha}^{-1}$, which was half the quantity that was lost from the Inceptisol. The OM seems to be also protected from microbial attack by entraptment within nanopores of allophanic aggregates.
The role of nanoclays in C stabilization in Andisols and Cambisols has been studied by Calabi-Floody et al. (2011; 2015). Recently the factors affecting the soil C stabilization in Andisols has been reviewed by Matus et al. (2014 and references there in). The interaction of HS with clay minerals have an influence on the surface area of the nanoprecipitates and on the stability of organic ligand to oxidation. Furthermore, the surface charge of variable mineral surfaces becomes more negative when organic ligands are held through ligand exchange.

Violante and Huang (1989) carried out experiments on the influence of oxidation treatments on the surface properties of short range ordered $\mathrm{Al}$ precipitation products formed by the interaction between $\mathrm{OH}-\mathrm{Al}$ species and selected organic ligands (citric, tartaric, aspartic and tannic acid) coprecipitated at $\mathrm{pH}$ 8.2. The residual $\mathrm{C}$ contents of the samples after $\mathrm{NaOCl}$ and $\mathrm{H}_{2} \mathrm{O}_{2}$ treatments ranged from 22 to $60 \%$ and from 55 to $90 \%$ of the original C contents, respectively (Table 4). A substantial proportion of C still remained in the $\mathrm{Al}$ precipitation products after treatments.

Table 4. Effects of $\mathrm{H}_{2} \mathrm{O}_{2}$ and $\mathrm{NaOCl}$ treatments on organic $\mathrm{C}$ contents of $\mathrm{Al}$ precipitation products formed in the presence of selected organic acids.

\begin{tabular}{ccccc}
\hline Ligand & $\mathrm{r}$ & \multicolumn{3}{c}{ Organic $\mathrm{C}\left(\mathrm{g} \mathrm{kg}^{-1}\right)^{*}$} \\
\cline { 2 - 5 } & $\mathrm{R}$ & No treatment & $\begin{array}{c}\text { After } \mathrm{H}_{2} \mathrm{O}_{2} \\
\text { treatment }\end{array}$ & $\begin{array}{c}\text { After } \mathrm{NaOCl} \\
\text { treatment }\end{array}$ \\
\hline Citric acid & 0.01 & 10 & 99 & 6 \\
Tannic acid & 0.01 & 100 & 55 & 22 \\
Tannic acid & 0.02 & 130 & 79 & 42 \\
Tannic acid & 0.10 & 302 & --- & 133 \\
Aspartic acid & 0.20 & 13 & 13 & 7 \\
\hline
\end{tabular}

*Average error $2.8 \%$. 
Contents of organic carbon which remained after the $\mathrm{NaOCl}$ treatment were less than those remaining after $\mathrm{H}_{2} \mathrm{O}_{2}$ treatment. Similar results were found by many authors with results obtained from soils. A possible explanation of the stability of organic substances is that organic ligands coprecipitated with $\mathrm{Al}$ were sorbed on external surfaces and incorporated in internal structures of $\mathrm{Al}$ precipitation products. Consequently, the organic $\mathrm{C}$ was protected and not easily oxidized.

In conclusion, in soils and related environments, abiotic and biotic components interact each other forming coprecipitates and organomineral complexes with peculiar properties and reactivity towards nutrients and pollutants. Researches on the properties of these coprecipitates and organomineral complexes are relatively poor if compared with the huge literature regarding the single soil components (clay minerals, organics, metal oxides, microorganisms). In future, the nature of synthetic and natural coprecipitates may be recognized in more detail by using different spectroscopic techniques, such as FSR, XAS, EXAFS, XANES spectroscopy.

\section{References}

Borda, M.J., Sparks, D.L. 2008. Mobility of trace elements in soil environments. In: A. Violante, P.M. Huang, G.M. Gadd. (eds). Biophysico-Chemical processes of metals and metalloids in soil environments. John Wiley \& Sons, Hoboken, NJ, USA, pp. 97-168.

Buondonno, A., Felleca, D., Violante, A. 1989. Properties of organo-mineral complexes formed by different addition sequences of hydroxy-Al, montmorillonite and tannic acid. Clays Clay Miner. 37, 235-242.

Buondonno, A., Violante, A. 1991. Titratable acidity of organo-mineral complexes as affected by mode of preparation, drying and stability of aggregates. Can. J. Soil Sci. 71, 285-292.

Calabi-Floody, M., Bendall, J.S., Jara, A.A., Welland, M.E., Theng, B.K.G., Rumpel, C., Mora, M.L. 2011. Nanoclays from an Andisol: Extraction, properties and carbon stabilization. Geoderma. 161, 159-167.

Calabi-Floody, M., Rumpel, C., Velásquez, G., Violante, A., Bol, R., Condron, L.M., Mora M.L. 2015. Role of Nanoclays in Carbon stabilization in Andisols and Cambisols. J.Soil Sci. Plant Nutr. 15, 587-604.

Caporale, A.G., Pigna, M., Dynes, J.J., Cozzolino, V., Zhu, J., and Violante, A. 2011. Effect of inorganic and organic ligands on the sorption/desorption of arsenate on/from $\mathrm{Al}-\mathrm{Mg}$ and $\mathrm{Fe}-\mathrm{Mg}$ layered double hydroxides. J. Hazar. Mat. 198, 291-299.

Caporale, A.G., Pigna, M., Azam, S.M.G.G., Sommella, A., Rao, M.A., Violante, A. 2013. Effect of competing ligands on the sorption/desorption of arsenite on/from $\mathrm{Mg}$-Fe layered double hydroxides (Mg-Fe-LDH). Chem. Engin. J. 225, 704-709.

Caporale, A.G., Violante, A. 2016. Chemical processes affecting the mobility of heavy metals and metalloids in soil environments. Curr. Pollution Rep. 2, 15-27.

Colombo, C., Violante, A. 1996. Effect of time and temperature on the chemical composition and crystallization of mixed iron and aluminum species. Clays Clay Miner. 44, 113-120.

Colombo, C., Ricciardella, M., Di Cerce, A., Maiuro, L., Violante, A. 2004. Effect of Tannate, pH, Sample Preparation, Aging, and Temperature on the Formation and Nature of Al-Oxyhydroxides. Clays Clay Miner. 52, 721-733.

Cornell, R.M., Schwertmann, U. 1996. The iron oxides. Structure, properties, reactions and uses. VCH Publ., New York, NY, USA. 
De Cristofaro, A., He, J.Z., Zhou, D.H., Violante, A. 2000. Sorption of phosphate and tartrate on aluminum-oxalate precipitates. Soil Sci. Soc. Am. J. 64, 1347-1355.

De Cristofaro, A., Violante, A. 2001. Effect of hydroxy-aluminum species on the adsorption and interlayering of proteic molecules onto montmorillonite. Appl. Clay Sci. 19, 59-67.

Goh, K.H., Lim, T.T., Dong, Z. 2008. Application of layered double hydroxides for removal of oxyanions: A review. Water Res. 42, 1343-1368.

Goh, T.B., Huang, P.M. 1986. Influence of citric and tannic acids on hydroxy-Al interlayering in montmorillonite. Clays Clay Miner. 34, 37-44.

Huang, P.M., Germida, J.J. 2002. Chemical and Biochemical Processes in the Rhizosphere: Metal Pollutants. In: P.M. Huang, J.M. Bollag, N. Senesi (eds). Interactions between Soil Particles and Microorganisms: Impact on the Terrestrial Ecosystem. John Wiley \& Sons, New York, NY, USA, pp. 381-438.

Kögel-Knabner, I., Amelung, W. 2014. Dynamics, Chemistry, and Preservation of Organic Matter in Soils. In: P.G. Falkowski, K.H. Freeman (eds). Treatise on Geochemistry, Second Edition. Elsevier Ltd., Chapter 7, Volume 12, Organic Geochemistry, pp. 157-215.

Jackson, T.A. 1998. The biogeochemical and ecological significance of interactions between colloidal minerals and trace elements. In: A. Parker, J.E. Rae (eds). Environmental Interactions of Clays, Springer-Verlag, Berlin.

Jara, A., Violante, A., Pigna, M., Mora, M.L. 2006. Mutual Interactions of Sulfate, Oxalate, Citrate and Phosphate on Synthetic and Natural Allophanes. Soil Sci. Soc. Am. J. 70, 337-346.

Lu, J., Liu, H., Liu, R., Zhao, X., Sun, L., Qu, J. 2013. Adsorptive removal of phosphate by a nanostruc- tured $\mathrm{Fe}-\mathrm{Al}-\mathrm{Mn}$ trimetal oxide adsorbent. Powder Technol. 233, 146-154.

Matus, F., Rumpel, C., Neculman, R., Panichini, M., Mora, M.L. 2014. Soil carbon storage and stabilization in andic soils. A review. Catena. 120, 102-110.

Mitsunobu, S., Takahashi, Y., Terada, Y., Sakata, M. 2010. Antimony(V) incorporation into synthetic ferrihydrite, goethite, and natural iron oxyhydroxides. Environ. Sci. Technol. 44, 3712-3718.

Pigna, M., Dynes, J.J., Violante, A., Sommella, A., Caporale, A.G. 2016. Sorption of arsenite on $\mathrm{Cu}-$ Al, Mg-Al, Mg-Fe and Zn-Al layered double hydroxides in the presence of inorganic anions commonly found in aquatic environments. Environ. Eng. Sci. 33, 98-104.

Prasanna, S.V., Vishnu-Kamath, P. 2009. Synthesis and characterization of arsenate-intercalated layered double hydroxides (LDHs): prospects for arsenic mineralization. J. Coll. Interface Sci. 331, 439-445.

Sommella, A., Caporale, A.G., Denecke, M.A., Mangold, S., Pigna, M., Santoro, A., Terzano, R., Violante, A. 2015. Nature and reactivity of layered double hydroxides formed by coprecipitating $\mathrm{Mg}$, $\mathrm{Al}$ and $\mathrm{As}(\mathrm{V})$ : effect of arsenic concentration, $\mathrm{pH}$, and aging. J. Hazard. Mater. 300, 504-512.

Sparks, D.L. 2003. Environmental Soil Chemistry. Second edition. Academic Press, San Diego, CA, USA.

Violante, A., Huang, P.M. 1989. Influence of oxidation treatments on surface properties and reactivities of short range ordered products of aluminum. Soil Sci. Soc. Am. J. 53, 1402-1407.

Violante, A., Gianfreda, L., Violante, P. 1993. Effect of prolonged aging on the transformation of shortrange ordered aluminum precipitation products formed in the presence of organic and inorganic ligands. Clays Clay Miner. 41, 353-359. 
Violante, A., Gianfreda, L. 1995. Adsorption of phosphate on variable charge minerals: Competitive effect of organic ligands. In: P.M. Huang et al. (eds). Environmental Impact of Soil Component Interactions. CRC Lewis Publ. London, UK, Volume II, Chapter 3, p. 29-38.

Violante, A., Rao, M.A., De Chiara, A., Gianfreda, L. 1996. Sorption of phosphate and oxalate on and release of sulfate from an aluminium hydroxy sulfate complex. Eur. J. Soil Sci. 47, 241-247.

Violante, A., Colombo, C., Cinquegrani, G., Adamo, P., Violante, P. 1998. Nature of mixed iron and aluminum gels as affected by $\mathrm{Fe} / \mathrm{Al}$ molar ratio, pH and citrate. Clay Miner. 33, 511-519.

Violante, A., Arienzo, M., Sannino, F., Colombo, C., Piccolo, A., Gianfreda, L. 1999. Formation and characterization of OH-Al-humate-montmorillonite complexes. Org. Geochem. 30, 461-468.

Violante, A. Gianfreda, L. 2000. Role of biomolecules in the formation of variable-charge minerals and organo-mineral complexes and their reactivity with plant nutrients and organics in soil. In: J.M. Bollag, G. Stotzky (eds). Soil Biochemistry. Marcel Dekker, New York, NY, USA, vol. 10, pp. 207-270.

Violante, A., Pigna, M. 2002. Competitive sorption of arsenate and phosphate on different clay minerals and soils. Soil Sci. Soc. Am. J., 66, 1788-1796.

Violante, A., Krishnamurti, G.S.R., Huang, P.M. 2002. Impact of Organic Substances on the Formation of Metal Oxides in Soil Environments. In: P.M. Huang, J.M. Bollag, N. Senesi (eds). Interactions Between Soil Particles and Microorganism: Impact on the Terrestrial Ecosystem. John Wiley \& Sons, New York, NY, USA, pp. 133-188.

Violante, A., Ricciardella, M., Pigna, M. 2003. Adsorption of heavy metals on mixed $\mathrm{Fe}-\mathrm{Al}$ oxides in the absence or presence of organic ligands. Water Air Soil Pollut. 40, 293-305.
Violante, A., Ricciardella, M., Pigna, M., Capasso, R. 2005. Effects of organic ligands on the sorption of trace elements onto metal oxides and organomineral complexes. In: P.M. Huang, G.R. Gobran (eds). Biogeochemistry of Trace Elements in the Rhizosphere. Elsevier B.V, 157-182.

Violante, A., Ricciardella, M., Del Gaudio, S., Pigna, M. 2006. Coprecipitation of Arsenate with Metal Oxides: Nature, Mineralogy and Reactivity of Aluminium Precipitates. Environ. Sci. Technol. 40, 4961-4967.

Violante, A., Del Gaudio, S., Pigna, M., Ricciardella, M. Benerjee, D. 2007. Coprecipitation of arsenate within metal oxides: 2 nature, mineralogy and reactivity of iron(III) precipitates. Environ. Sci. Technol. 41, 8275-8280.

Violante, A., Krishnamurti, G.S.R., Pigna, M. 2008. Mobility of Trace Elements in Soil Environments. In: A. Violante, P.M. Huang, G. Gadd (eds). Biophysico-Chemical Processes of Metals and Metalloids in Soil Environments. John Wiley \& Sons, Hoboken, NJ, USA, pp. 168-213.

Violante, A., Pucci, M., Cozzolino, V., Zhu, J., Pigna, M. 2009a. Sorption/desorption of arsenate on/ from $\mathrm{Mg}-\mathrm{Al}$ layered double hydroxides: Influence of phosphate. J. Colloid Interface Sci. 333, 63-70.

Violante, A., Cozzolino, V., Del Gaudio, S., Benerjee, D., and Pigna, M. 2009b. Coprecipitation of arsenate within metal oxides: 3 nature, mineralogy and reactivity of iron(III)/Al precipitates. Environ. Sci. Technol. 43, 1515-1521.

Violante, A., Cozzolino, V., Perelomov, L., Caporale, A.G., Pigna, M. 2010. Mobility and bioavailability of heavy metals and metalloids in soil environments. J. Soil Sci. Plant Nutr. 10, 268-292.

Violante, A., Pigna, M., Cozzolino, V., Huang, P.M. 2012. Impact of soil physical, chemical and biological interactions on the transformation of metals and metalloids. In: P.M. Huang, Y. Li, M.E. 
Summer (eds). Handbook of Soil Science Resource of Management and Environmental Impacts, Second Edition. CRC Press, Taylor \& Francis, Chapter 8, pp. 1-29.

Violante, A. 2013. Elucidating Mechanisms of Competitive Sorption at the Mineral/Water Interface. In: D.L. Sparks (ed). Adv. Agron. 118, 111-176.

Violante, A., Caporale, A.G. 2015. Biogeochemical processes at soil-root interface. In: L. Gianfreda (ed). Biogeochemical processes in the rhizosphere and their influence on plant nutrition. J. Soil Sci. Plant Nutr. 15, 422-448.
Yuan, G., Theng, B.K.G. 2012. Clay-organic interactions in soil environments. In: P.M. Huang, Y. Li, M.E. Sumner (eds). Handbook of Soil Sciences. Resource Management and Environmental Impact. CRC Press Taylor and Francis Group, Boca Raton, FL, USA.

Wang, Y., Morin, G., Ona-Nguema, G., Juillot, F., Guyot, F., Calas, G., Brown, G.E. 2010. Evidence for different surface speciation of arsenite and arsenate on green rust: an EXAFS and XANES study. Environ. Sci. Technol. 44, 109-115.

Zanzo, E., Balint, R., Prati, M., Celi, L., Barberis, E., Violante, A., Martin, M. 2017. Aging and arsenite loading control arsenic mobility from ferrihydrite-arsenite coprecipitates. Geoderma. 299, 91-100. 